\title{
Interaction microenvironment - Pantoea agglomerans limits maize yield
}

\author{
La interacción microclima - Pantoea agglomerans limita el rendimiento de maíz \\ Daniel Ruíz Juárez ${ }^{1,4}$, Alejandro Azaola Espinosa', Gilberto Esquivel Esquivel ${ }^{3}$, \\ Eva Segundo Pedraza ${ }^{4}$, and Hilda Victoria Silva Rojas ${ }^{5:}$
}

\footnotetext{
${ }^{1}$ Programa Doctorado Ciencias Biológicas y de la Salud, Universidad Autónoma Metropolitana-Conacyt. Calzada del Hueso 1100, Coyoacán. 04960 CDMX, México.

${ }^{2}$ Universidad Autónoma Metropolitana, Departamento Sistemas Biológicos. Calzada del Hueso 1100, Coyoacán. 04960 CDMX, México.

*Autores responsables (azaola@correo.xoc.uam.mx); (hsilva@colpos.mx)

${ }^{3}$ Instituto Nacional de Investigaciones Forestales, Agrícolas y Pecuarias. Carretera Los Reyes-Texcoco km 13.5. 56250 Coatlinchán, Texcoco, Edo. de México.

${ }^{4}$ Universidad Autónoma Metropolitana, Departamento de Producción Agrícola y Animal, Calzada del Hueso 1100, Coyoacán. 04960 CDMX, México.

${ }^{5}$ Colegio de Postgraduados, PREGEP-Producción de Semillas, Campus Montecillo. 56230 Montecillo, Edo. de México, México.
}

\section{SUMMARY}

Pantoea agglomerans has been reported as the cause of chlorotic streaks on maize leaves in the Central High Valleys of México (CVHM), but there are no current data of how the infection of this new pathogen in Mexico affects production and yield of the crop. To understand the development of the disease in the crop, two experiments with a split-plot design and three replications were established during spring-summer 2010 in different microenvironments: Ayapango and Temamatla. Three cultivars of maize (a tri-linear HS2 hybrid, the single-cross hybrid Triunfo and the native Cacahuacintle) were evaluated with three $P$. agglomerans isolates. In the three maize cultivars, chlorotic streaks appeared on new leaves; at the ripening stage, the symptoms were less perceptible. The average incidence of plants with chlorotic streaks was higher in the town of Temamatla than in Ayapango, and in both microenvironments, the average degree of severity was less than $40 \%$. Isolate A was the most virulent $(P<0.0001)$ on the three cultivars evaluated. These results will provide the basis for effective management of the disease under environmental conditions similar to those evaluated in this research.

Index words: chlorotic streaks, Pantoea agglomerans, maize disease, microclimate.

Cita recomendada:

Ruíz Juárez, D., A. Azaola Espinosa, G. Esquivel Esquivel, E. Segundo Pedraza, and H. V. Silva Rojas. 2017. Interaction microenvironment - Pantoea agglomerans limits maize yield. Terra Latinoamericana 36: 75-83.

DOI: https://doi.org/10.28940/terra.v36i1.374

\section{RESUMEN}

Pantoea agglomerans ha sido reportada como la causa de estrías cloróticas en las hojas de maíz en los Valles Altos Centrales de México, aún no existen datos de incidencia o gravedad actuales para este nuevo patógeno en el cultivo. Para comprender el desarrollo de la enfermedad en el campo, se establecieron dos experimentos con un diseño de parcelas divididas y tres repeticiones durante el ciclo primavera-verano de 2010 en dos localidades: Ayapango y Temamatla. Se evaluaron tres cultivares de maíz (un híbrido tri-lineal HS2, el híbrido de cruza simple Triunfo y el Cacahuacintle nativo) con tres aislamientos de $P$. agglomerans. Los datos del progreso de la enfermedad se estimaron a partir de los datos de incidencia y severidad en el tiempo, y para indicar las diferencias significativas entre los tratamientos con un intervalo de confianza del $\alpha=0.05$. En los tres cultivares de maíz aparecieron estrías cloróticas en las hojas nuevas; en la etapa de maduración, los síntomas fueron menos perceptibles. La incidencia promedio de plantas con estrías cloróticas fue mayor en la localidad de Temamatla que en Ayapango, y en ambos lugares, el grado promedio de severidad fue menor al $40 \%$. El aislado A fue el más virulento $(P<0.0001)$ en los tres cultivares evaluados. Estos resultados proporcionarán la base para el manejo efectivo de la enfermedad en condiciones ambientales similares a las evaluadas en esta investigación.

Recibido: octubre de 2017. Aceptado: diciembre de 2017. Publicado en Terra Latinoamericana 36: 75-83. 
Palabras clave: estrías cloróticas, Pantoea agglomerans, infección en maíz, microclima.

\section{INTRODUCTION}

Growing human population demands intensive increment in agricultural activity to produce foods from plant origin. The impact of environmental stress and the appearance of diseases caused by fungal or bacterial species are the major constraints to production (Boyd et al., 2013). Maize (Zea mays L.) is one of the crops most used worldwide: an average harvested area of 157 million hectares and production of 781 mega tons from 2000 to 2014. It is a vital source of food security in many countries in North and Latin America and Sub-Saharan Africa (Ramírez-Cabral et al., 2017). México, with 8 million hectares of maize, contributes a production of 18 mega tons, of which 2.3 million tons are grown in the State of Mexico, the third largest producer of maize nationally, mostly by producers who farm ejidos or communal lands (Paulino-Flores et al., 2017). These producers are identified as being particularly sensitive to negative impacts of global economic integration and market liberalization (Eakin, 2005).

Among the biotic factors, bacteria are an important group of phytopathogens that affect crop health and the phytosanitary quality of seed. The first bacterial attacks in maize were reported in 1949. Now, reports of diseases include several symptoms, which are shown in Table 1.
The causal agent of the diseases and chlorotic streak symptoms described above are Gram negative microorganisms from the Enterobacteriaceae family that have a Type III secretion system with the ability to export proteins involved in the process of colonizing the intercellular spaces of plant tissues and cause death (Collmer et al., 2000). This secretion system has been reported in plant pathogens including Pantoea stewartii subp stewartii, Pseudomonas, Erwinia, Xanthomonas, Ralstonia (Collmer et al., 2000) and Agrobacterium vitis and has been associated with the production of exopolysaccharide (EPS), which causes vascular occlusion (Chalupowicz et al., 2008). In P. agglomerans (Barash and Manulis-Sasson, 2007), because of the occlusions caused by EPS produced by this bacterium, symptoms such as chlorotic streaks, water-soaked necrotic spots and putrescence have been reported in microenvironments significantly different in terms of temperature, humidity and species of plants. Small or large climate variations and its correlation with bacterial diseases is a current global concern about the extent and importance of causes and of its effects that affect the incidence and prevalence of symptoms and loss of crops in a worldwide. Bacterial wilt, chlorotic streaks, necrosis are an important bacterial maize disease throughout the world from North to South America (Forgey et al., 1982; Smidt and Vidaver, 1986; Valencia-Torres et al., 2004; Albarracin-Orio et al., 2012), Africa (Coutingo and Wallis, 1991), Asia (Hui-Ying et al., 2011) and Europe (Krawczyk

Table 1. Reported diseases caused by bacterial attack in maize.

\begin{tabular}{lll}
\hline Disease & Causal agent & Reference \\
\hline Striped disease & Xanthomonas campestris pv. zeae & Coutingo and Wallis, 1991 \\
Goss's bacterial wilt & $\begin{array}{l}\text { Clavibacter michiganensis subsp. nebraskensis (= Corynebacterium } \\
\text { michiganense subsp. nebraskense) }\end{array}$ & Smidt and Vidaver, 1986 \\
Bacterial wilt or Stewart's wilt & Pantoea stewartii (= Erwinia stewartii) & Forgey et al., 1982 \\
Holcus spot & Pseudomonas syringae pv. syringae & Kendrick, 1926 \\
Bacterial foliar wilt & Acidovorax avenae subsp. avenae (= Pseudomonas avenae) & Johnson et al., 1949 \\
Bacterial stalk rot & Dickeya chrysanthemi f. sp. zeae (= Erwinia chrysanthemi) & Sah and Arny, 1990 \\
Bacterial stripe and leaf spot & Burkholderia andropogonis (= Pseudomonas andropogonis) & Vidaver and Carlson, 1978 \\
Chocolate spot & Pseudomonas syringae pv. coronafaciens & Ribeiro et al., 1977; White, 2004 \\
Maize brown stalk rot & Pantoea ananatis & Goszczynska et al., 2007; Krawczyk et al., 2010 \\
Bacterial stripe and stem rot & B. andropogonis & Gijón-Hernández et al., 2008 \\
Bacterial wilt & P. stewartii & Valencia-Torres et al., 2004 \\
Foliar bacterial wilt & A. avenae subsp. avenae & CIMMYT, 2004 \\
Brown stalk rot caused & P. ananatis & Gijón-Hernández et al., 2008 \\
\hline
\end{tabular}


et al., 2010) and with different cultivar as pearl millet (Frederickson et al., 1997), rice (Lee et al., 2010) and cotton (Medrano and Bell, 2007).

In Mexico, there are no reports of this disease or its symptoms, and because maize is the most important food source for the Mexican population, it is important to know how the disease manifested as chlorotic streaks caused by $P$. agglomerans affects maize production. This knowledge will enable the development of management programs. The aim of this work was to study how the bacteria $P$. agglomerans affects maize yield when it is inoculated in different environmental conditions on three maize cultivars adapted to two locations in the Central High Valleys of Mexico.

\section{MATERIALS AND METHODS}

\section{Experimental Zone}

Two experimental locations were established in the state of Mexico (Figure 1). Temamatla (19 $12^{\prime} \mathrm{N}$ and $\left.98^{\circ} 52^{\prime} \mathrm{W}\right)$, altitude of $2260 \mathrm{~m}$ above sea level, humidity of $45-70 \%$ and temperature of $17-20^{\circ} \mathrm{C}$ and the second location, Ayapango $\left(19^{\circ} 8^{\prime} \mathrm{N}\right.$ and $\left.98^{\circ} 48^{\prime} \mathrm{W}\right)$, altitude of $2440 \mathrm{~m}$ above sea level, humidity of $50-90 \%$ and temperature of $15-18{ }^{\circ} \mathrm{C}$. (SMN, 2012; INEGI, 2013).

\section{Genetic Material}

Three maize cultivars were used: the tri-linear HS2 hybrid (cross: CL12 $\times$ CL11 $\times$ CL7) from the Colegio de Postgraduados in Montecillo, Mexico; a simple-cross Triunfo hybrid (cross between lines L-10 and L-52) (Bravo-Quirino and Muñoz-González,

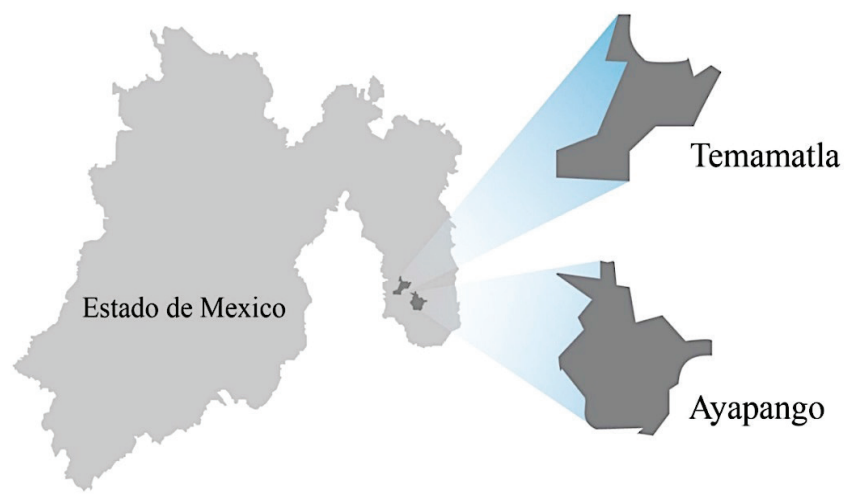

Figure 1. Geographic location of the experimental maize fields in the State of Mexico, during the 2010 spring-summer cycle.
2003) from the National Institute of Research in Forestry, Agriculture and Fishing (INIFAP); and the native Cacahuacintle from CHVM. The two improved cultivars and native maize were developed at altitudes of 2200 to 2750 meters above sea level.

\section{Experimental Units}

A split-plot design with randomized complete blocks was used (Figure 2). The largest unit was represented by the maize cultivars, with subunits for each of the isolates. Each block consisted of 12 treatments with three replicates, resulting in a total of 36 experimental units. Each unit consisted of four 10 -m-long rows $0.8 \mathrm{~m}$ apart and $0.2 \mathrm{~m}$ between plants. A fertilization formula of $160 \mathrm{~N}-60 \mathrm{P}-00 \mathrm{~K}$ was applied. Fieldwork was performed manually or with machinery, depending on the conditions in CHVM.

\section{Origin of the Inoculum Source}

The P. agglomerans bacterial isolates $\mathrm{A}, \mathrm{B}$ and $\mathrm{C}$ were obtained from maize plants with symptoms of chlorotic streaks in the experimental fields of the Colegio de Postgraduados. These isolates were previously identified by sequencing the $16 \mathrm{~S}$ rRNA gene. Molecular analysis of sequences showed that they were 99\% similar to the sequences for the $P$. agglomerans cluster, while the control strain of $P$. agglomerans ATCC 27155 showed 98-99\% similarity. Sequences were deposited in GenBank (Accession Nos. EF050806 to EF050810). The isolates were maintained at $-80{ }^{\circ} \mathrm{C}$ in a solution of $25 \%$ glycerol (Morales-Valenzuela et al., 2007; Silva-Rojas et al., 2007).
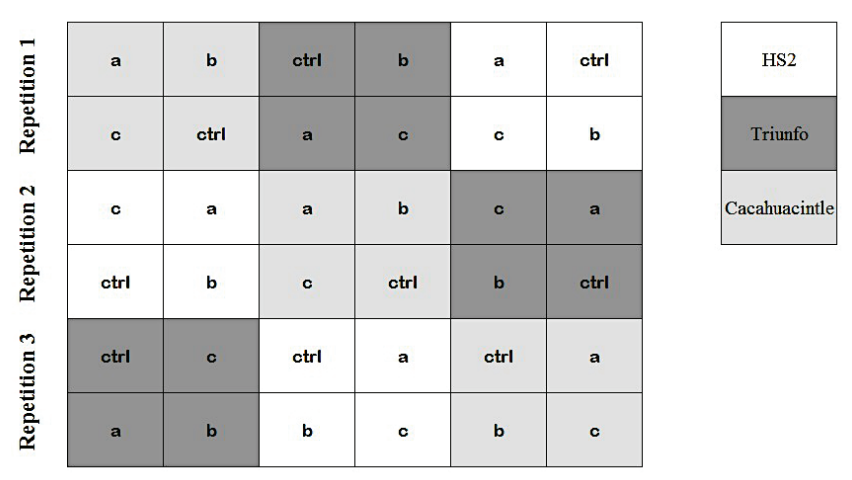

Figure 2. Model of the split-plot design with randomized complete blocks used. a,b,c means the $\boldsymbol{P}$. agglomerans bacterial isolates. Ctrl means controls and colors means the cultivars. 


\section{Activation and Inoculum Preparation}

To activate the bacteria, each isolate was seeded with the cross-streak method over CPG (Bioxon ${ }^{\circledR}$, México) (10 g casamino acid, $10 \mathrm{~g}$ peptone, $10 \mathrm{~g}$ glucose and $18 \mathrm{~g}$ agar) and the cells were grown at $28^{\circ} \mathrm{C}$. After $48 \mathrm{~h}$, pale yellow colonies characteristic of $P$. agglomerans were observed. The isolates of $P$. agglomerans were inoculated in chalk-agar culture medium (10 g yeast extract, 20 g glucose, $20 \mathrm{~g}$ calcium carbonate and $17 \mathrm{~g}$ agar). The isolates were incubated at $28^{\circ} \mathrm{C}$ for $48 \mathrm{~h}$. For each isolate, a bacterial suspension of $10^{8} \mathrm{CFU} \mathrm{mL} \mathrm{m}^{-1}$ was prepared using sterile distilled water (Schaad et al., 2001).

\section{Inoculation of Maize Seedlings with $P$. agglomerans}

For each experimental unit, 10 maize plants from the central rows were selected. P. agglomerans inoculation was performed on maize plants with six true leaves (phenological stage V3) (CIMMYT, 2012) 30 days after sowing by the injection method on the stem $2 \mathrm{~cm}$ above the ground (Hui-Ying et al., 2011; Lamka et al., 1991). One $\mathrm{mL}$ of bacterial suspension with $10^{8} \mathrm{CFU}$ was injected. As the negative control, $1 \mathrm{~mL}$ of sterile distilled water was used. At the end of the experiment, leaves with symptoms were collected for each strain. Koch's postulates were validated in maize plants inoculated with P. agglomerans.

\section{Measuring Disease Progress in Maize}

After harvesting and based on the presence of chlorotic streaks in inoculated maize leaves, the yield of each treatment was recorded by location, cultivar and isolates. For each treatment ear weight, width and length were evaluated, as well as grain number and weight.

\section{Statistical Analysis}

The effect of the disease on yield was determined per treatment and analysed statistically with SAS V9.3 software (SAS, 2014). The program design was developed for a split-plot experimental design (Littell et al., 2006) with the following model:

$\mathrm{y}_{\mathrm{ijk}}=\mu+\mathrm{Blo}_{\mathrm{j}}+\alpha_{\mathrm{i}}+\beta_{\mathrm{k}}+(\alpha \beta)_{\mathrm{ik}}+\eta_{\mathrm{ij}}+\mathrm{e}_{\mathrm{ijk}}$

where $y_{i j k}$ is the response variable associated with level $\mathrm{k}$ of the factor in the small plot within the large plot in the $\mathrm{j}^{\text {th }}$ block that received the $\mathrm{i}^{\text {th }}$ level applied to the large plot, $B l_{j}$ is the effect of the $\mathrm{j}^{\text {th }}$ block, $\alpha_{\mathrm{i}}$ is the main effect of the $i^{\text {th }}$ level of the factor applied to the large plot (A), $\beta_{\mathrm{k}}$ is the main effect of the $\mathrm{k}^{\text {th }}$ level of the factor applied to the small plot $(B),(\alpha \beta)_{\mathrm{ik}}$ is the interaction between factor $A$ and factor $B, \eta_{i j}$ is a common random effect for all subplots in the large plot $(i, j)$ and $e_{i j k}$ is a random component particular to the subplot with the $\mathrm{k}^{\text {th }}$ level of the small plot in the largest plot $(i, j)$. Significant differences were analysed with ANOVA and the Tukey test with $P<0.05$.

\section{RESULTS AND DISCUSSION}

Chlorotic streaks in the inoculated plants were observed 8 days after inoculation. Figure 3 shows the

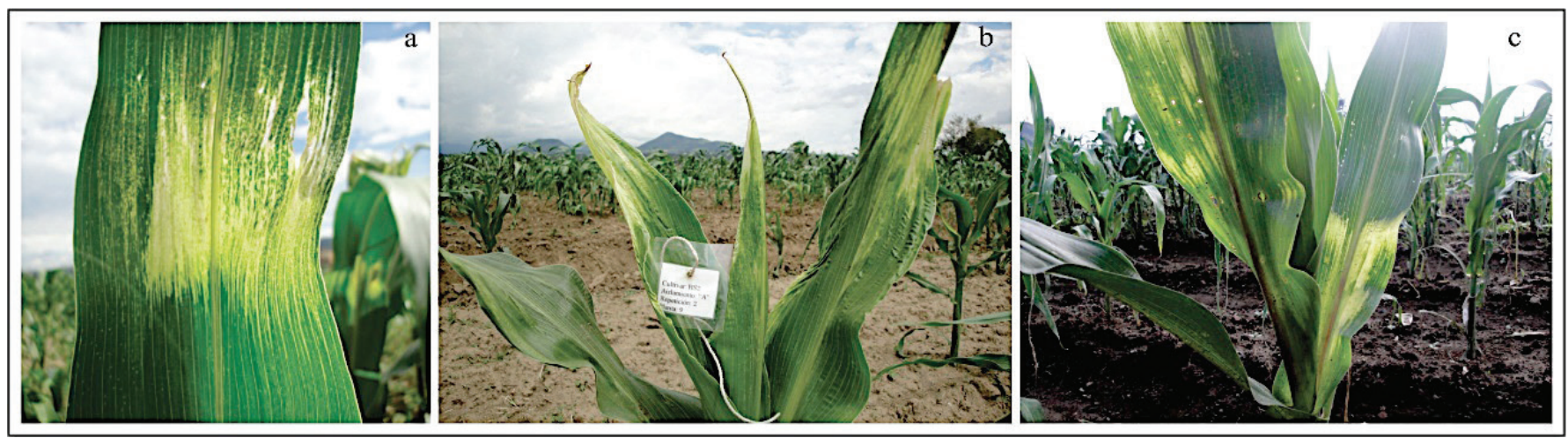

Figure 3. Symptoms of chlorotic streaks on leaves of Triunfo hybrid maize in the experimental fields of Temamatla and Ayapango, México, during the 2010 spring-summer cycle: a) development of chlorotic streaks on the edges of the leaves parallel to the midrib; b) development of chlorotic streaks in the middle layer of the leaves; c) development of chlorotic streaks on the edges and shortening of the leaves in the middle lamella. 
development of chlorotic streaks parallel to the midrib of the leaf, located on the edge, the main ridge, the apex of the leaf blade and near the ligule. Dispersed aqueous stains, tissue contraction in the affected area, undulations in the area with chlorotic streaks, shortening of leaves, curl of the apex of the leaf blade and, in advanced stages of the disease, necrosis and loosening of the leaf blade were also observed.

\section{Chlorotic Streak Symptoms on Maize Plant}

Figure 4 shows the cumulative incidence of plants with chlorotic streaks by location after 7 days of inoculation, the percentage of infected plants was less than $15 \%$. For both microenvironments, the largest number of plants with chlorotic streaks was observed between 7 and 14 days after inoculation. The percentage of plants with chlorotic streaks was $92 \%$ in Temamatla and $70 \%$ in Ayapango. Both microenvironments showed significant differences among isolates $(P<0.0001)$ and over time $(P<0.0001)$. Differences in incidence were caused by different isolates: in Ayapango isolate A was highly virulent, and in Temamatla isolate $\mathrm{B}$ was more virulent.

\section{Maize Yield in Plants with Chlorotic Streaks}

Symptoms of chlorotic streaks were observed in $60 \%$ of inoculated plants (Figure 5). In Ayapango, the
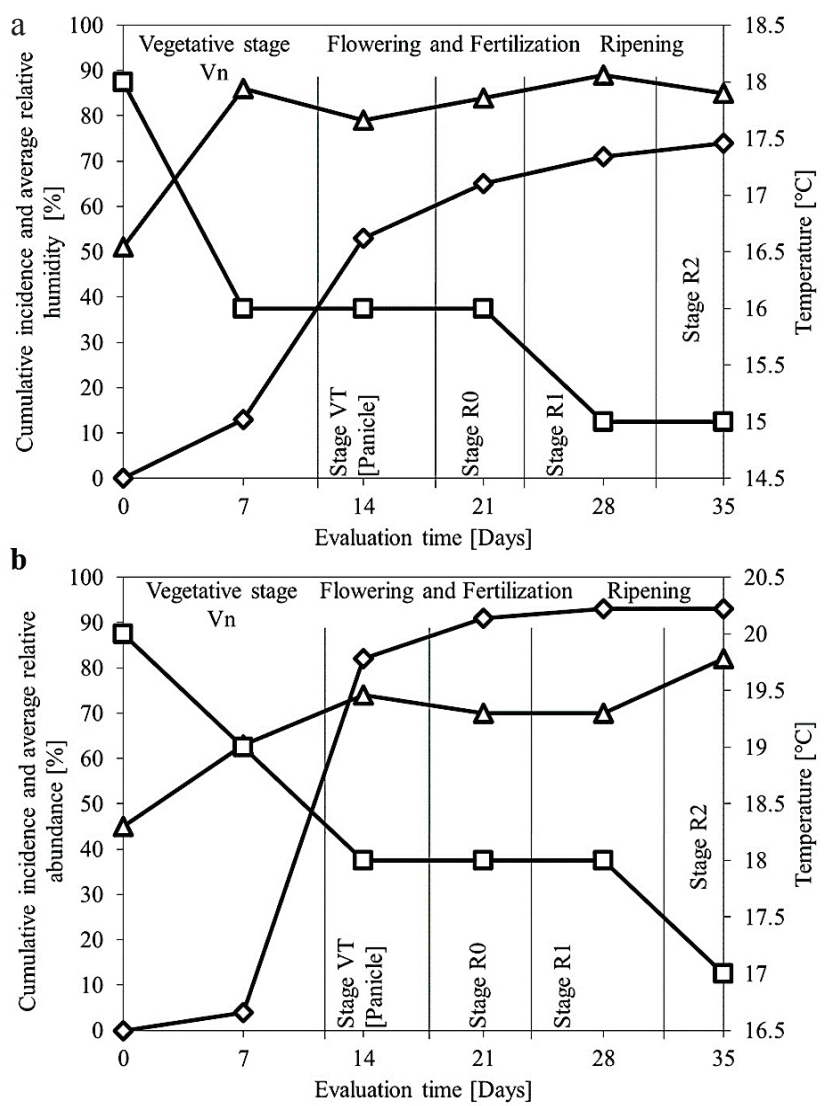

Figure 4. Advance of lesion in leaves of maize plants caused by inoculation of the bacteria in two locations of the Central High Valleys of Mexico. a: Ayapango and b: Temamatla. $\diamond$ : incidence; $\square$ : average temperature; $\Delta$ : average relative humidity.

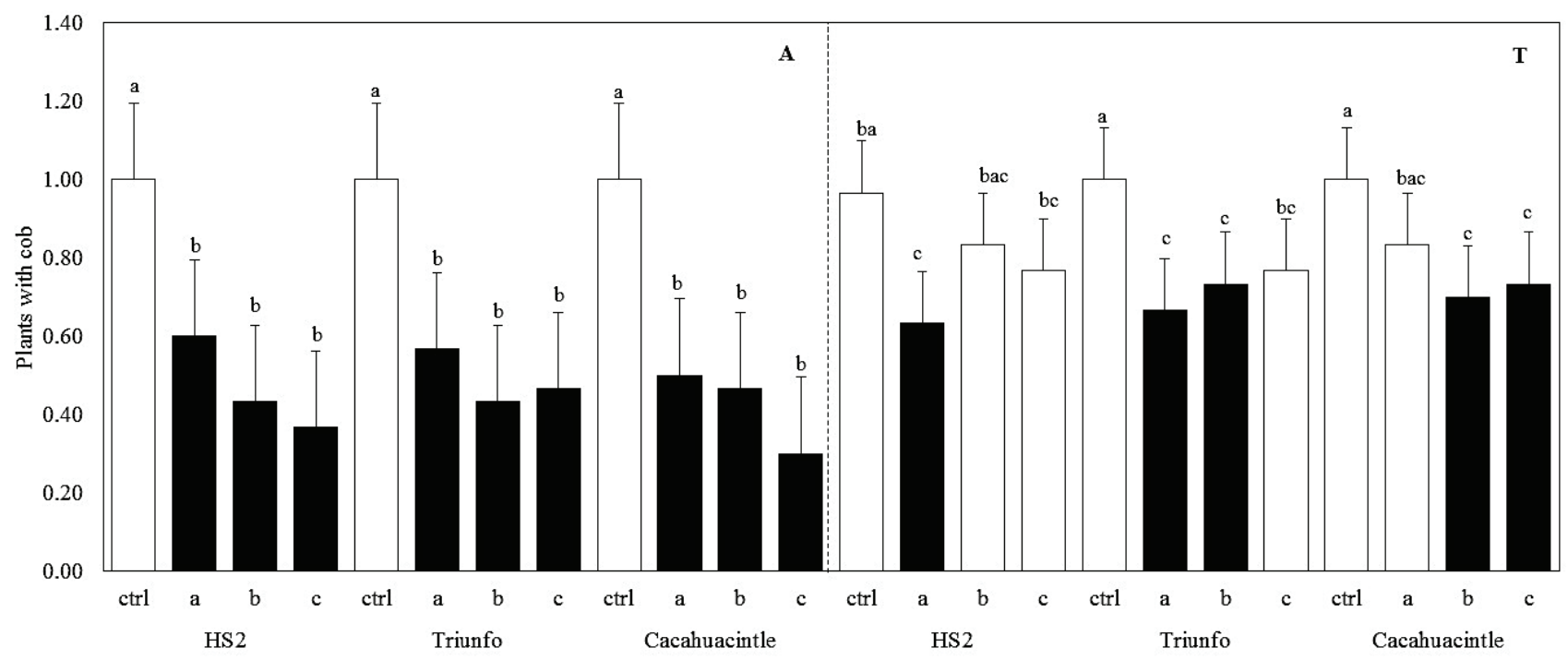

Figure 5. Percent of plants with chlorotic streaks and fruit development in two locations A (Ayapango) and T (Temamatla) and three isolate $a, b, c$. 
number of plants with fruit was lower in all the cultivars and for all the isolates $(P<0.0001)$. In Temamatla; all cultivars were highly susceptible, but to different isolates: HS2 to P. agglomerans isolate A; Triunfo to $P$. agglomerans isolate $\mathrm{A}$ and $\mathrm{B}$ and Cacahuacintle to P. agglomerans isolates B and C (Figure 5 and Table 2).

By location, in Ayapango, the cultivar and isolate effects on the variables cob length, width and weight were significant. Grain number and weight were influenced by the interaction cultivar * isolate. In Temamatla, the cultivar-isolate interaction affected all the yield variables (Table 2).

Average size of ears on plants with chlorotic streak was smaller, relative to the control: width $5.2 \pm 0.57 \mathrm{~cm}$, length $14.80 \pm 3.07 \mathrm{~cm}$ and weight $175.73 \pm 62.65 \mathrm{~g}$. Plants without inoculation with $P$. agglomerans (controls) had ears $5.32 \pm 0.46 \mathrm{~cm}$ wide, $15.77 \pm$ $2.51 \mathrm{~cm}$ long, weighing $195.20 \pm 55.29 \mathrm{~g}$. The average values of grain number and weight, were $405.82 \pm$ 116.38 and $136.38 \pm 50.27 \mathrm{~g}$, significantly lower than the control: $443.12 \pm 110.21$ and $162.21 \pm 49.26 \mathrm{~g}$.

As shown in Table 3, the cultivar-isolate interaction was significant in all variables. In both locations, cultivar HS2 and Cacahuacintle had the smallest dimensions. Ear width was smallest in Ayapango with the interaction location-isolate $\mathrm{C}$ and in Temamatla with the cultivar Triunfo and isolate $\mathrm{A}$, and in both locations the interaction Cacahuacintle-isolate $\mathrm{C}$ was significant.

The Central Valleys of the State of Mexico are notable for their production of maize (500 $000 \mathrm{ha}$ ), $80 \%$ of which is rainfed. Climate in this region is temperate and humid, with an average annual temperature of $16.5^{\circ} \mathrm{C}$, relative humidity of $85 \%$, and annual rainfall of $800-900 \mathrm{~mm}$, at an altitude of 2200 meters above sea level (SMN, 2012). These conditions are favourable for maize cultivation but allow the development of bacterial diseases, such as chlorotic streaks on maize leaves caused by $P$. agglomerans.

In this research, during the period of evaluation of chlorotic streaks, average humidity and temperature in Ayapango and Temamatla were $45 \%$ and $85 \%$ and $16-19{ }^{\circ} \mathrm{C}$, respectively. Under these conditions, the incidence of maize plants with chlorotic streaks increased gradually in the three cultivars of maize (Figure 3). Differences between both locations (Temamatla and Ayapango) during the evaluation were found. In Temamatla the humidity was lower than Ayapango (70 and $90 \%$ respectively) and the temperature was $2{ }^{\circ} \mathrm{C}$ higher in Temamatla.

Table 2. Effect of inoculating $P$. agglomerans on the yields of cob and grain by location and cultivars.

\begin{tabular}{|c|c|c|c|c|c|c|c|}
\hline \multirow[t]{2}{*}{ Effect } & & \multirow[b]{2}{*}{ Plants with cob } & \multicolumn{3}{|c|}{$\mathrm{Cob}$} & \multicolumn{2}{|c|}{ Grain } \\
\hline & & & Width & Length & Weight & Number & Weight \\
\hline \multicolumn{8}{|c|}{ CHVM } \\
\hline & Location & $<0.0001$ & $<0.0001$ & 0.8985 & $<0.0001$ & 0.116 & 0 \\
\hline & Cultivar & 0.956 & $<0.0001$ & 0.002 & $<0.0001$ & $<0.0001$ & $<0.0001$ \\
\hline & Isolate & 0.587 & 0.006 & $<0.0001$ & $<0.0001$ & $<0.0001$ & $<0.0001$ \\
\hline & Location*Cultivar & 0.739 & 0.335 & 0.748 & 0.141 & 0.378 & 0.294 \\
\hline & Location*Isaloate & 0.22 & 0.604 & 0.537 & 0.019 & 0.99 & 0.165 \\
\hline & Location*Cultivar*Isolate & 0.672 & 0.419 & 0.243 & 0.107 & 0.283 & 0.183 \\
\hline & Cultivar*Isolate & 0.866 & 0.0382 & 0.015 & $<0.0001$ & 0.002 & $<0.0001$ \\
\hline \multicolumn{8}{|c|}{ Ayapango } \\
\hline & Cultivar & 0.818 & $<0.0001$ & 0.025 & $<0.0001$ & $<0.0001$ & $<0.0001$ \\
\hline & Isolate & 0.268 & 0.18 & 0.002 & 0.003 & 0.012 & 0.005 \\
\hline & Cultivar*Isolate & 0.939 & 0.153 & 0.264 & 0.157 & 0.022 & 0.03 \\
\hline \multicolumn{8}{|c|}{ Temamatla } \\
\hline & Cultivar & 0.894 & $<0.0001$ & 0.05 & $<.0001$ & $<.0001$ & 0 \\
\hline & Isolate & 0.775 & 0.0308 & 0.007 & $<0.0001$ & 0.003 & $<0.0001$ \\
\hline & Cultivar*Isolate & 0.418 & 0.1227 & 0.008 & $<0.0001$ & 0.022 & 0 \\
\hline
\end{tabular}


Table 3. Effect of inoculation of three $P$. agglomerans isolates on ear and grain yields by location and cultivar.

\begin{tabular}{|c|c|c|c|c|c|c|}
\hline \multirow{2}{*}{ Cultivar } & \multirow{2}{*}{ Isolate } & \multicolumn{3}{|c|}{$\mathrm{Cob}$} & \multicolumn{2}{|c|}{ Grain } \\
\hline & & Width & Length & Weight & Number & Weight \\
\hline & & $\ldots \ldots-\cdots$ & $\mathrm{cm} \ldots \ldots$ & $-\ldots g-\ldots$ & & $\ldots$ - . - - \\
\hline \multicolumn{7}{|l|}{ Ayapango } \\
\hline \multirow[t]{4}{*}{ HS2 } & $\operatorname{ctrl}$ & $4.96 \pm 0.34 \mathrm{dc}^{\dagger}$ & $15.18 \pm 1.67 \mathrm{ba}$ & $176.49 \pm 32.71 \mathrm{bc}$ & $480.50 \pm 87.79 b c$ & $155.94 \pm 28.68 \mathrm{bac}$ \\
\hline & $\mathrm{a}$ & $5.00 \pm 0.46 \mathrm{dc}$ & $15.62 \pm 1.79 \mathrm{ba}$ & $191.81 \pm 47.28 \mathrm{bac}$ & $481.00 \pm 102.97 \mathrm{bdc}$ & $144.10 \pm 41.20 \mathrm{ba}$ \\
\hline & $\mathrm{b}$ & $5.01 \pm 0.37 \mathrm{~d}$ & $14.82 \pm 1.88 \mathrm{ba}$ & $181.49 \pm 49.85 \mathrm{bac}$ & $454.47 \pm 75.41 \mathrm{dc}$ & $148.32 \pm 35.27 \mathrm{bc}$ \\
\hline & $\mathrm{c}$ & $4.83 \pm 0.42 \mathrm{~d}$ & $14.16 \pm 2.63 \mathrm{bc}$ & $170.73 \pm 47.30 \mathrm{bc}$ & $451.69 \pm 100.77 \mathrm{dc}$ & $148.61 \pm 45.54 \mathrm{bac}$ \\
\hline \multirow[t]{4}{*}{ Triunfo } & ctrl & $5.48 \pm 0.54 \mathrm{ba}$ & $16.69 \pm 2.80 \mathrm{a}$ & $225.14 \pm 71.23 \mathrm{a}$ & $557.70 \pm 145.85 \mathrm{a}$ & $185.03 \pm 60.52 \mathrm{a}$ \\
\hline & $\mathrm{a}$ & $5.45 \pm 0.75 \mathrm{bac}$ & $15.08 \pm 3.70 b c$ & $215.74 \pm 113.84 \mathrm{ba}$ & $446.71 \pm 165.43 \mathrm{dc}$ & $129.61 \pm 72.07 \mathrm{bc}$ \\
\hline & $\mathrm{b}$ & $5.54 \pm 0.45 \mathrm{a}$ & $15.92 \pm 3.37 \mathrm{ba}$ & $223.43 \pm 57.64 \mathrm{a}$ & $561.25 \pm 137.12 \mathrm{ba}$ & $170.16 \pm 45.73 \mathrm{a}$ \\
\hline & $\mathrm{c}$ & $5.51 \pm 0.34 \mathrm{ba}$ & $15.35 \pm 3.30 \mathrm{ba}$ & $194.97 \pm 5820 \mathrm{bac}$ & $504.22 \pm 169.37 \mathrm{bac}$ & $137.09 \pm 49.47 \mathrm{bac}$ \\
\hline \multirow[t]{4}{*}{ Cacahuacintle } & ctrl & $5.52 \pm 0.49 \mathrm{a}$ & $15.44 \pm 3.07 \mathrm{ba}$ & $183.96 \pm 61.93 \mathrm{bac}$ & $291.17 \pm 96.99 \mathrm{e}$ & $145.67 \pm 58.60 \mathrm{bac}$ \\
\hline & $\mathrm{a}$ & $5.31 \pm 0.78 \mathrm{bac}$ & $14.73 \pm 3.46 \mathrm{ba}$ & $161.61 \pm 76.82 \mathrm{c}$ & $278.39 \pm 94.99 \mathrm{e}$ & $127.14 \pm 66.62 \mathrm{bc}$ \\
\hline & $\mathrm{b}$ & $5.20 \pm 0.58 \mathrm{bdc}$ & $15.00 \pm 3.18 \mathrm{bc}$ & $152.29 \pm 64.62 \mathrm{c}$ & $255.13 \pm 101.10 \mathrm{e}$ & $107.08 \pm 59.60 \mathrm{dc}$ \\
\hline & $\mathrm{c}$ & $4.91 \pm 1.02 \mathrm{dc}$ & $12.07 \pm 4.37 \mathrm{~b}$ & $89.56 \pm 48.34 \mathrm{~d}$ & $219.55 \pm 100.33 \mathrm{e}$ & $115.34 \pm 36.90 \mathrm{~d}$ \\
\hline \multicolumn{7}{|l|}{ Temamatla } \\
\hline \multirow[t]{4}{*}{ HS2 } & $\operatorname{ctrl}$ & $4.63 \pm 0.69 b$ & $14.84 \pm 2.25 \mathrm{ba}$ & $150.75 \pm 57.59 \mathrm{dc}$ & $480.50 \pm 155.89 b c$ & $140.45 \pm 48.18 \mathrm{bcd}$ \\
\hline & $\mathrm{a}$ & $4.56 \pm 0.32 b$ & $14.32 \pm 3.57 b$ & $144.93 \pm 61.05$ dce & $481.00 \pm 141.58 \mathrm{c}$ & $125.11 \pm 56.88 \mathrm{fecd}$ \\
\hline & $\mathrm{b}$ & $4.69 \pm 0.33 \mathrm{ba}$ & $15.11 \pm 2.73 \mathrm{ba}$ & $164.35 \pm 50.30 \mathrm{c}$ & $454.47 \pm 126.43 \mathrm{bc}$ & $140.20 \pm 45.58 \mathrm{bcd}$ \\
\hline & $\mathrm{c}$ & $5.24 \pm 2.05 \mathrm{ba}$ & $15.29 \pm 3.07 \mathrm{~b}$ & $187.00 \pm 61.71 \mathrm{bc}$ & $451.69 \pm 112.36 \mathrm{bc}$ & $154.23 \pm 61.11 \mathrm{bc}$ \\
\hline \multirow[t]{4}{*}{ Triunfo } & ctrl & $11.18 \pm 31.39 \mathrm{a}$ & $32.25 \pm 81.34 \mathrm{a}$ & $224.31 \pm 58.34 \mathrm{a}$ & $557.70 \pm 158.67 \mathrm{a}$ & $182.52 \pm 56.81 \mathrm{a}$ \\
\hline & $\mathrm{a}$ & $4.90 \pm 0.65 \mathrm{ba}$ & $13.53 \pm 2.70 \mathrm{~b}$ & $121.91 \pm 64.92 \mathrm{dfe}$ & $446.71 \pm 160.22 \mathrm{c}$ & $101.18 \pm 59.78 \mathrm{gf}$ \\
\hline & $\mathrm{b}$ & $5.03 \pm 0.73 \mathrm{ba}$ & $16.65 \pm 3.15 \mathrm{a}$ & $193.90 \pm 51.79 \mathrm{ba}$ & $561.25 \pm 123.64 \mathrm{ba}$ & $151.98 \pm 62.07 \mathrm{ba}$ \\
\hline & $\mathrm{c}$ & $4.87 \pm 1.03 \mathrm{ba}$ & $13.80 \pm 3.51 \mathrm{~b}$ & $142.60 \pm 51.54$ dce & $504.22 \pm 141.00 \mathrm{c}$ & $113.64 \pm 51.85 \mathrm{gfecd}$ \\
\hline \multirow[t]{4}{*}{ Cacahuacintle } & $\operatorname{ctrl}$ & $5.10 \pm 0.42 \mathrm{ba}$ & $15.07 \pm 2.46 \mathrm{ba}$ & $159.43 \pm 54.62 \mathrm{c}$ & $291.17 \pm 75.12 \mathrm{~d}$ & $137.44 \pm 48.14$ becd \\
\hline & $\mathrm{a}$ & $4.84 \pm 0.62 \mathrm{ba}$ & $14.57 \pm 2.75 b$ & $127.00 \pm 49.62 \mathrm{dfe}$ & $278.39 \pm 77.18 \mathrm{~d}$ & $110.92 \pm 45.34 \mathrm{gfe}$ \\
\hline & $\mathrm{b}$ & $4.70 \pm 0.77 \mathrm{ba}$ & $13.41 \pm 2.56 \mathrm{~b}$ & $101.87 \pm 52.56 \mathrm{f}$ & $255.13 \pm 89.59 \mathrm{~d}$ & $89.82 \pm 44.24 \mathrm{~g}$ \\
\hline & $\mathrm{c}$ & $4.68 \pm 0.42 \mathrm{ba}$ & $13.86 \pm 3.75 b$ & $112.62 \pm 57.24 \mathrm{fe}$ & $219.55 \pm 111.33 \mathrm{~d}$ & $111.35 \pm 73.50 \mathrm{gfed}$ \\
\hline
\end{tabular}

These findings probably had influence in the incidence of plants with chlorotic streaks. Probably the bacteria requires a lower humidity to express its pathogenicity.

Morales-Valenzuela et al. (2007) found similar results when they inoculated maize and sorghum seedlings with $P$. agglomerans under greenhouse conditions. Frederickson et al. (1997) found that at $25{ }^{\circ} \mathrm{C}$ and $95 \%$ relative humidity, different isolates of $P$. agglomerans caused necrosis on the leaves and edges of pearl millet (Pennisetum glaucum (L.) R. Br.).

Similarly, Sabaratnam and Beattie (2001) reported that when maize plants are grown in relative humidity below 95\%, colonisation of $P$. agglomerans in leaf tissue increases. However, when maize plants are exposed to $45 \%$ relative humidity, colonisation decreases drastically.

In the two locations, maize yield was affected by $P$. agglomerans when relative humidity was $85 \%$. Differences of $\pm 3{ }^{\circ} \mathrm{C}$ in temperature caused lower yield compared with the controls. The affinity of P. agglomerans to the cultivar Cacahuacintle is probably due to the high concentration of carbohydrates, of which more than $73 \%$ is amylopectin (Carballo et al., 2010), in contrast to cultivar HS2 and Triunfo. Loss of grain weight of the cultivar Cacahuacintle reduces productivity by $1.9 \mathrm{Mg} \mathrm{ha}^{-1}$ meaning economic repercussions for the producers (Téllez-Silva et al., 2016). 


\section{CONCLUSIONS}

Symptom development was mainly observed in maize leaves during vegetative growth in the three cultivars. The percentage of diseased plants exhibited behaviour characteristic of bacterial diseases: stage $\mathrm{Vn}$ was the most affected and in stage R2 the disease stabilised. This behaviour correlated with temperature and relative humidity in the CHVM during the springsummer 2010 crop season. The three evaluated maize cultivars were susceptible to the three isolates of $P$. agglomerans. Disease symptoms correlated with loss of ear and grain yield, but posterior effects of these symptoms on yield is still unknown. Therefore, it is necessary to correlate these symptoms with maize growth and yield. This is the first report in Mexico that describes the infection of $P$. agglomerans and how the chlorotic streak symptoms can vary in two similar microenvironments

\section{ACKNOWLEDGEMENTS}

We thank the following institutions: Genetic Resources and Productivity-Seed Production Program of the Colegio de Postgraduados and National Institute of Research in Forestry, Agriculture and Fishing (INIFAP), State of Mexico, for providing the Triunfo seeds used in this research. We also thank Dr. Paulino Pérez-Rodríguez for his suggestions regarding the statistical analysis.

\section{Disclosure Statement}

The authors declare that the research was conducted in the absence of any commercial or financial relationships that could be construed as a potential conflict of interest.

\section{REFERENCES}

Albarracin-Orio, A. G., E. Brücher, M. C. Plazas, P. Sayago, F. Guerra, R. De Rossi, D. A. Ducasse, and G. D. Guerra. 2012. First report of Stewart's wilt of maize in Argentina caused by Pantoea stewartii. Plant Dis. 96: 1819.3.

Baird, R. E., R. D. Gitaitis, and G. A. Herzog. 1997. Firts report of cotton lint rot by Pantoea agglomera

Barash, I. and S. Manulis-Sasson. 2007. Virulence mechanisms and host specificity of gall-forming Pantoea agglomerans. Trends Microbiol. 15: 538-545.
Boyd, A., C. Ridout, D. M. O’Sullivan, J. E. Leach, and H. Leung. 2013. Plant-pathogen interactions: disease resistance in modern agriculture. Trends Gen. 29: 233-240.

Bravo-Quirino, F. y F. Muñoz-González. 2003. Maíz triunfo híbrido de doble propósito para valles altos, México. ICAMEX. Metepec, Edo. de México, México.

Carballo, C. A y M. E. Ramírez. 2010. Manual gráfico para la descripción varietal en maíz. CP-SNICS. México, D. F.

Chalupowicz, L., S. Manulis-Sasson, M. Itkin, A. Sacher, G. Sessa, and I. Barash. 2008. Quorum-sensing system affects gall development incited by Pantoea agglomerans pv. gypsophilae. Mol. Plant Microbe Interact. 21: 1094-1105. doi:10.1094/ MPMI -21-8-1094.

CIMMYT (Centro Internacional de Mejoramiento de Maíz y Trigo). 2004. Maize diseases: a guide for field identification. CIMMYT. México, D. F.

Collmer, A., J. L. Badel, A. O. Charkowski, W. L. Deng, D. E. Fouts, A. R. Ramos, A. H. Rehm, D. M. Anderson, O. Schneewind, K. V. van Dijk, and J. R. Alfano. 2000. Pseudomonas syringae Hrp type III secretion system and effector proteins. PNAS 97: 8770-8777.

Coutingo, T. A. and F. M. Wallis. 1991. Bacterial streak disease of maize (Zea mays L.) South Africa. J. Phytopathol. 133: 112-120.

Eakin, H. 2005. Institutional change, climate risk, and rural vulnerability: Cases from Central Mexico. World Developm. 33: 1923-1938. doi: 10.1016/j.worlddev.2005.06.005.

Forgey, W., M. H. Blanco, L. L. Darrah, and M. S. Zumber. 1982. Prediction of Stewart's wilt disease in single and three way crosses in maize. Plant Dis. 66: 1159-1162.

Frederickson, D. E., E. S. Monyo, S. B. King, and G. N. Odvody. 1997. A disease of pearl millet in Zimbabwe caused by Pantoea agglomerans. Plant Dis. 81: 959. doi: 10.1094/ PDIS.1997.81.8.959D.

Gijón-Hernández, A., D. Téliz-Ortiz, E. Cárdenas-Soriano, C. de León, A. Mora-Aguilera, A., D. Mejía-Sánchez, and R. de la Torre-Almaraz. 2008. Leaf stripe and stem rot caused by Burkholderia gladioli, a new disease of maize in México. Plant Dis. 92: 1249.

Goszczynska, T., W. J. Botha, S. N. Venter, and T. A. Coutinho, T. A. 2007. Isolation and identification of the causal agent of brown stalk rot, a new disease of maize in South Africa. Plant Dis. 91: 711-718.

Hui-Ying, C., Z. Li-Qun, Z. Zhen-Dong, W. Xiao-Ming, L. HongJie, and R. Zheng-Guang, R. 2011. Cloning of a pathogenicity gene $y$ hfk from Pantoea agglomerans on maize inbred line PS056. Sci. Agric. Sinica 44: 299-306.

INEGI (Instituto Nacional de Estadística y Geografía). 2013. Geografía, México. http://www3.inegi.org.mx/sistemas/ mexicocifras/default.aspx?e=13. (Consulta: septiembre 3-4, 2010).

Johnson, A. G., A. L. Robert, and L. Cash. 1949. Bacterial leaf blight and stalk rot of maize. J. Agric. Res. 78: 719-732.

Kendrick, J. B. 1926. Holcus bacterial spot of Zea mays and Holcus species. Research Bulletin (Iowa Agriculture and Home Economics Experiment Station) 7: 303-334.

Krawczyk, K., J. Kamasa, A. Zwolinska, and H. Pospieszny. 2010. First report of Pantoea ananatis associated with leaf spot disease of maize in Poland. J. Plant Pathol. 92: 807-811. 
Lamka, G. L., J. H. Hill, D. C. McGee, and E. J. Braun. 1991. Development of an immunosorbent assay for seedborne Erwinia stewartii in maize seeds. Phytopathology 81: 839-846.

Lee, H. B., J. P. Hong, and S. B. Kim, S. 2010. First report of Leaf blight caused by Pantoea agglomerans on rice in Korea. Plant Dis. 94: 1372.2.

Littell, R. C., W. W. Stroup, G. A. Milliken, R. D. Wolfinger, and O. Schabenberger. 2006. SAS for mixed models. SAS Institute Inc. Cary, NC, USA.

Medrano, E. G. and A. A. Bell. 2007. Role of Pantoea agglomerans in opportunistic bacterial seed and boll rot of cotton (Gossypium hirsutum) grown in the field. J. Appl. Microbiol. 102: 134-143.

Morales-Valenzuela, G., H. Silva-Rojas, D. Ochoa-Martínez, E. Valadez-Moctezuma, B. Alarcon-Zuniga, L. X. ZelayaMolina, L. Córdova-Téllez, L. Mendoza-Onofre, H. VaqueraHuerta, and A. Carballo-Carballo. 2007. First report of Pantoea agglomerans causing leaf blight and vascular wilt in maize and Sorghum in Mexico. Plant Dis. 91: 1365.

Paulino-Flores, M., A. R. Martínez-Campos, F. E. MartínezCastañeda, C. A. López-Orona, I. Vizcarra-Bordi, and N. Munguía. 2017. Evaluation of the sustainability of hybrid and native maize production system. J. Cleaner Product. 150: 287293. doi: 10.1016/j.jclepro.2017.02.182.

Ramírez-Cabral, N. Y. Z., L. Kumar, and F. Shabani. 2017. Global alterations in areas of suitability for maize production from climate change and using a mechanistic species distribution model (CLIMEX). Sci. Rep. 7: 5910. doi:10.1038/s41598017-05804-0.

Ribeiro, R. de L. D., R. D. Durbin, D. C. Arny, and T. F. Uchytil. 1977. Characterization of the bacterium inciting chocolate spot of maize. Phytopathology 67: 1427-1431.
Sabaratnam, S. and G. A. Beattie. 2001. Differences in the leaf colonization pattern of two bacterial species. Phytopathology 91: S78.

Sah, D. N. and D. C. Arny. 1990. Susceptibility of maize germplasm to bacterial stalk rot caused by Erwinia chrysanthemi pv. zeae. Trop. Pest Manage. 36: 154-156.

SAS Institute. 2014. SAS-STAT® 9.3 user's guide. SAS Institute Inc. Cary, NC, USA.

Schaad, N. W., J. B. Jones, and W. Chun. 2001. Laboratory guide for identification of plant pathogenic bacteria. APS Press. St. Paul, USA. [Internet]. Available from: https://www.cabdirect. org/cabdirect/abstract/20013064240. (Consulta: septiembre $3-4,2010)$.

Silva-Rojas, H. V., A. Farfán-Gómez, B. Alarcon-Zuniga, D. L. Ochoa-Martinez, and L. X. Zelaya-Molina. 2007. Pantoea agglomerans causing wilt and leaf spots in Zea mays in the Central Highland Valley of Mexico. Phytopathology 97: S108.

Smidt, M., and A. K. Vidave. 1986. Population dynamics of Clavibacter michiganense subsp. nebraskense in field-grown dent maize and popmaize. Plant Dis. 70: 1031-1036.

SMN (Servicio Meteorológico Nacional). 2012. Temperatura y precipitación [Internet]. Available from: http://smn.conagua. gob.mx (Consulta: septiembre 3-4, 2010).

Téllez-Silva, J. M., F. Herrera-Tapia, I. Vizcarra-Bordi y J. J. Ramírez-Hernández. 2016. El maíz Cacahuacintle y su potencial para el desarrollo endógeno: el caso de Santa María Nativitas. Espacialidades 6: 168-191.

Valencia-Torres, N., M. Mezzalama, S. G. Leyva-Mir, and D. P. Jeffers. 2004. Detection of maize bacterial wilt, Pantoea stewartii (smith) mergaert, verdonck and kersters, in the central valley of Mexico. Rev. Mex. Fitopatol. 22: 308-314.

Vidaver, A. M. and R. R. Carlson. 1978. Leaf spot of field maize caused by Pseudomonas andropogonis. Plant Dis. 62: 213-216. 